Cite this: NewJ.Chem., 2013 37, 1417

Received (in Montpellier, France) 8th February 2013, Accepted 16th February 2013 DOI: 10.1039/c3nj00157a www.rsc.org/njc

\section{Synthesis of donor-substituted meso-phenyl and meso-ethynylphenyl BODIPYs with broad absorption $†$}

\author{
Katja Gräf, ${ }^{a}$ Thomas Körzdörfer, ${ }^{b}$ Stephan Kümmel ${ }^{b}$ and Mukundan Thelakkat*a
}

\section{Introduction}

The 4,4-difluoro-4-bora-3a,4a-diaza-s-indacenes, better known as BODIPYs, ${ }^{1}$ have emerged as attractive compounds for many research areas, including the application as laser dyes, ${ }^{2}$ biochemical labeling agents, ${ }^{3}$ fluorescence sensors ${ }^{4} /$ switches $^{5}{ }^{5}$ electroluminescent materials ${ }^{6}$ or molecular photonics. ${ }^{7}$ The large variety of applications of this class of dyes are based on their outstanding properties. ${ }^{8-10}$ BODIPYs are thermally and photochemically stable, chemically robust, redox active and highly fluorescent. Most importantly, they are characterized by an intensive absorption profile in the visible region that can be easily tuned by chemical modification of the BODIPY core. ${ }^{9}$ This feature makes these dyes highly interesting for the application as sensitizers in solar cells because it provides the opportunity to improve the light harvesting by the extension of the absorption. However, their use as sensitizers and donor

\footnotetext{
${ }^{a}$ University of Bayreuth, Macromolecular Chemistry I, Applied Functional Polymers, D-95447 Bayreuth, Germany. E-mail: Mukundan.Thelakkat@uni-bayreuth.de; Fax: +49 92155 3109; Tel: +49 921553108

${ }^{b}$ University of Bayreuth, Theoretical Physics IV, D-95447 Bayreuth, Germany $\dagger$ Electronic supplementary information (ESI) available: Mechanisms of the Knoevenagel-type condensation, NMR-spectra, UV/vis-spectra, fluorescence-spectra, cyclic voltammetry data. See DOI: 10.1039/c3nj00157a
}

materials in solar cells is in its infancy and the efficiencies are still low. It has been shown that BODIPYs can be used as sensitizers in solid-state dye-sensitized solar cells, ${ }^{11}$ liquid electrolyte dye-sensitized solar cells ${ }^{12-14}$ and also as active material in organic bulk heterojunction solar cells. ${ }^{15}$

In the present work we focused on the structural modification of the BODIPY core to accomplish excellent optical properties with the goal of improving the light harvesting in solar cells. For this, panchromatic absorption behaviour accompanied by high extinction coefficients has to be realized. Therefore, we synthesized a series of BODIPY dyes differing in the meso-substituent and the groups at positions 3 and 5 (see 5, 8, 13 and 16, Scheme 1). From the literature it is known that arylation at the meso-position affects the optical and electrochemical properties only marginally. ${ }^{16}$ The reason for this is the orthogonal orientation of the meso-phenyl moiety relative to the planar BODIPY core. This configuration reduces the conjugation between the two units. To improve the conjugation and thus the extent of absorption, we introduced an ethynyl-bridge between the mesophenyl group and the BODIPY core creating meso-ethynylphenyl BODIPYs $(13,16)$. The idea was to enable an efficient delocalization due to the comparatively diffuse nature of the $\pi$-bonds of the ethynyl-bridge creating a cylindrical electron cloud around the $\sigma$-bond. Porphyrin chemistry has already shown 
that ethynyl-type bridges can bring about strong electronic interactions between two connected moieties. ${ }^{17}$ For the synthesis of such meso-ethynylphenyl BODIPYs, we successfully used the condensation of an alkynyl aldehyde with a pyrrole derivative. To further increase the extent of the absorption, we attached strong donor groups to the BODIPY core via vinylic bonds. To this end, 4,4'-dimethoxytriphenylamine (MeOTPA) was selected. MeOTPA is a strong donor due to the high electron density and the high lying HOMO level. It is also stable against oxidative coupling. Finally, a 2-cyano-3-acrylic acid anchoring moiety was attached to the each BODIPY dye making them suitable for the application in hybrid solar cells. The structural, optical, electrochemical and photovoltaic properties of the meso-phenyl $(5,8)$ and mesoethynylphenyl BODIPYs $(\mathbf{1 3}, \mathbf{1 6})$ bearing methyl or MeOTPA groups at positions 3 and 5 were compared. Their applicability as sensitizers for $\mathrm{TiO}_{2}$ for light harvesting and energy conversion was tested in hybrid solar cells.

\section{Results and discussion}

\section{Synthesis}

The synthetic routes for the preparation of the target BODIPYs 5, 8, 13 and 16 are depicted in Scheme 1. The meso-phenyl derivatives 5 and $\mathbf{8}$ were prepared according to a conventional coupling method using an aromatic aldehyde (Scheme 1, route a). ${ }^{14}$ Thus 5 and 8 were both obtained from $\mathbf{3}$, which was synthesized from 4-(1,3-dioxolan-2-yl)benzaldehyde 1 and kryptopyrrole 2. Deprotection of 3 and subsequent Knoevenagel condensation with 2-cyanoacetic acid resulted in the formation of 5 . For obtaining 8, the MeOTPA-donor had to be attached first to 3 . Therefore, 4-(di(4-methoxyphenyl)amino)benzaldehyde was reacted with the methyl groups of 3 at the positions 3 and 5 by a Knoevenagel-type condensation to yield $\mathbf{6}$. After the deprotection of the aldehyde functionality, the resulting compound 7 was condensed with 2-cyanoacetic acid to yield $\mathbf{8}$.

For the synthesis of the meso-ethynylphenyl BODIPYs, we developed a novel route (Scheme 1 , route b). These BODIPYs were synthesized starting from a non-aromatic aldehyde, viz. an alkynyl aldehyde (9). Typically aromatic aldehydes, acid chlorides or anhydrides are used for the preparation of BODIPYs. To the best of our knowledge, no alkenyl or alkynyl aldehydes have been used for this reaction. However, a comparable reaction route is already known from porphyrin chemistry where 9 was reacted with pyrrole to give the associated dipyrromethane and finally the meso-ethynyl porphyrin. ${ }^{18,19}$ The meso-ethynylphenyl BODIPYs (13 and 16) were synthesized starting from kryptopyrrole 2 and the alkynyl aldehyde 3-(trimethylsilyl)-2-propynal 9 to give 10. After deprotection of 10, a Sonogashira coupling of 11 with the final 4-(2-carboxy-2-cyanovinyl)phenyl anchoring group 12 was performed to yield directly the meso-ethynylphenyl BODIPY 13. To get the MeOTPA-substituted meso-ethynyl counterpart of $\mathbf{8}$, the TMS-protected meso-ethynyl BODIPY 10 was used for the Knoevenagel-type condensation with 4-(di(4-methoxyphenyl)amino)benzaldehyde. To this end, the aromatic aldehyde was reacted with the 3,5-dimethyl BODIPY $\mathbf{1 0}$ in the presence of a piperidine/glacial acetic acid or a piperidine $/ p$-toluenesulfonic acid catalyst system in non-polar solvents such as benzene or toluene. The proposed mechanism of this reaction is presented in the ESI. $\dagger$ The basicity and nucleophilicity of the amine used generally determine the mechanism, either as the Hann-Lapworth (Fig. S1, ESI $\dagger$ ) or the organocatalytic (Fig. S2, ESI $\dagger$ ) mechanism; both being well-studied for a variety of such condensations. ${ }^{20,21}$ For instance, the Hann-Lapworth mechanism is the only valid mechanism for reactions including tertiary amines because they cannot perform a nucleophilic attack on the carbonyl carbon of aldehydes as required in the organocatalytic mechanism. For reactions using primary or secondary amines either mechanism are conceivable and piperidine is a common secondary amine used for this reaction. But as we performed the reaction with 2,2,6,6-tetramethyl-piperidine (TMP) which is also a secondary amine and as basic as piperidine but much more bulky, we observed no reaction (even after one week under reflux). Similarly, by using the tertiary base $\mathrm{NEt}_{3}$ (which has also a comparable basicity), we did not observe a condensation reaction. Thus bases with the comparable basicity as piperidine that are not able to activate the aldehyde did not promote the Knoevenagel condensation at all. Moreover, we isolated the aminal (structure B, Fig. S2 and S3, ESI $\dagger$ ) expected in an organocatalytic route. From these results it can be deduced that the organocatalytic mechanism is relevant for the condensation between BODIPYs and donor aldehydes. The proposed mechanism in Fig. S2 (ESI $\dagger$ ) is further supported by the exclusive formation of trans-substituted BODIPYs (see ${ }^{1} \mathrm{H}-\mathrm{NMR}$ spectra of 8 and 16, Fig. S4 and S5, ESI, $\dagger$ respectively). In this way, $\mathbf{1 4}$ could be synthesised from $\mathbf{1 0}$ in a Knoevenagel-type condensation. After deprotection of 14, 15 was reacted with 12 in a Sonogashira coupling to afford 16. All compounds were characterized using FT-IR, ${ }^{1} \mathrm{H}-\mathrm{NMR}$, UV/vis and cyclic voltammetry measurements.

\section{Characterization by NMR}

NMR analysis was used to investigate (1) the influence of the meso-substituent on the electronic and magnetic environment of the BODIPY scaffold, (2) the stereochemistry of the vinyl bonds and (3) the geometry of the 4-(2-carboxy-2-cyanovinyl)phenyl anchoring unit.

The influence of the meso-substituent was examined by comparing the ${ }^{1} \mathrm{H}-\mathrm{NMR}$ spectra of 18, 3 and 17 (Fig. 1, full spectra in Fig. S7, ESI $\dagger$ ) differing only in the substituent at the meso position: meso-proton, meso-phenyl and meso-ethynylphenyl. The main difference between meso-phenyl and meso-ethynylphenyl BODIPYs is the chemical shift of the resonance signal assigned to the 1,7-methyl groups of the BODIPY core. These occur at about $1.28 \mathrm{ppm}$ for meso-phenyl derivatives (e.g. 3), whereas they occur at about $2.53 \mathrm{ppm}$ for the meso-ethynylphenyl BODIPYs (e.g. 17). This gives clear evidence that the chemical and/or magnetic environment of these protons is strongly influenced by the substituent at the meso-position. Relative to the corresponding meso-proton compound 18, the orthogonal phenyl moiety in $\mathbf{3}$ seems to increase the electron density and hence the shielding of the 1,7-methyl groups. The interesting resonance signal appears at a distinctly lower 
a)

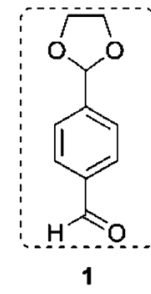<smiles>CCCCCc1c(C)[nH]c(C)c1CC</smiles>

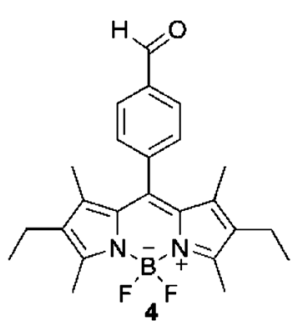

(ii)

(iii)
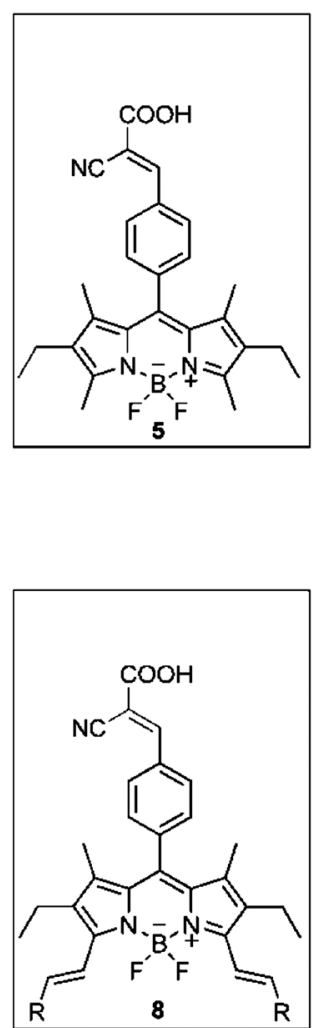

b)<smiles>CCc1c(C)c[nH]c1C</smiles>

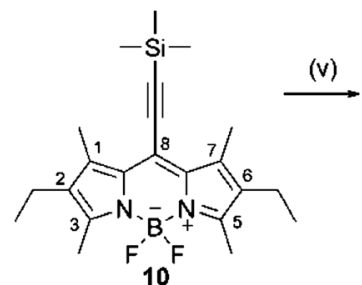

| (iv)

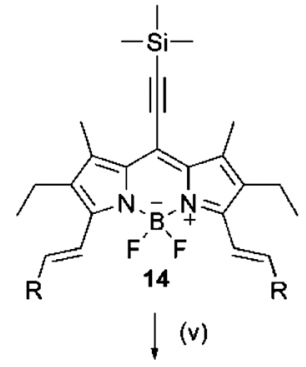<smiles></smiles>

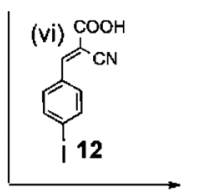

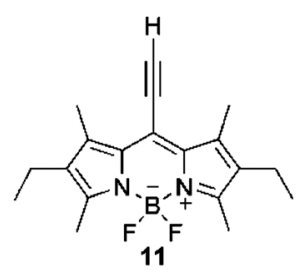
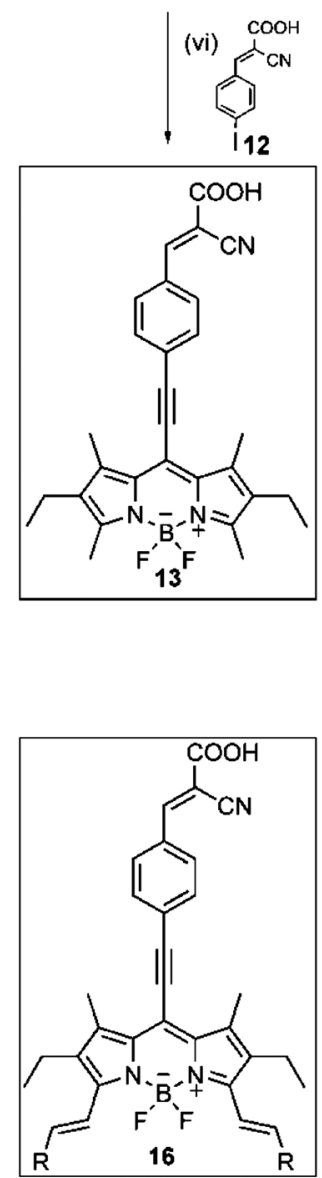

Scheme 1 Synthetic routes for the preparation of (a) the meso-phenyl BODIPYs (5 and 8) and (b) the meso-ethynylphenyl BODIPYs (13 and 16). (i) Trifluoroacetic acid, 2,3-dichloro-5,6-dicyano-1,4-benzoquinone, $\mathrm{NEt}_{3}, \mathrm{BF}_{3} \cdot \mathrm{OEt}_{2}$, in $\mathrm{CH}_{2} \mathrm{Cl}_{2}$, RT. (ii) $5 \% \mathrm{HCl}_{\text {aq, }}$ in THF, RT. (iii) 2-Cyanoacetic acid, piperidine, in acetonitrile, reflux. (iv) 4-(Di(4-methoxyphenyl)amino)benzaldehyde, piperidine, glacial acetic acid, in benzene, reflux. (v) KF, in MeOH or MeOH: $\mathrm{THF}_{1} 1: 1, \mathrm{RT}$. (vi) Pd(PPh $)_{4}, \mathrm{Cul}, \mathrm{NEt}{ }_{3}$, in THF, RT.

ppm value for 3 . This is not due to the $+\mathrm{M}$-effect of the phenyl group because it is not in conjugation with the BODIPY core. One possible influence affecting the shift is the spatial proximity between the electron density of the meso-phenyl ring and that of the methyl groups. However, the main effect influencing the shift is the ring current of the meso-phenyl group.
Consequently, the generated magnetic field weakens the applied one at the 1,7-methyl groups, which necessitates a higher external field. This equals a shift of the signal to lower ppm values. Therefore, it can be deduced that the meso-phenyl group does not influence the electron density at the 1,7-methyl groups by conjugation, but rather by the spatial proximity. 


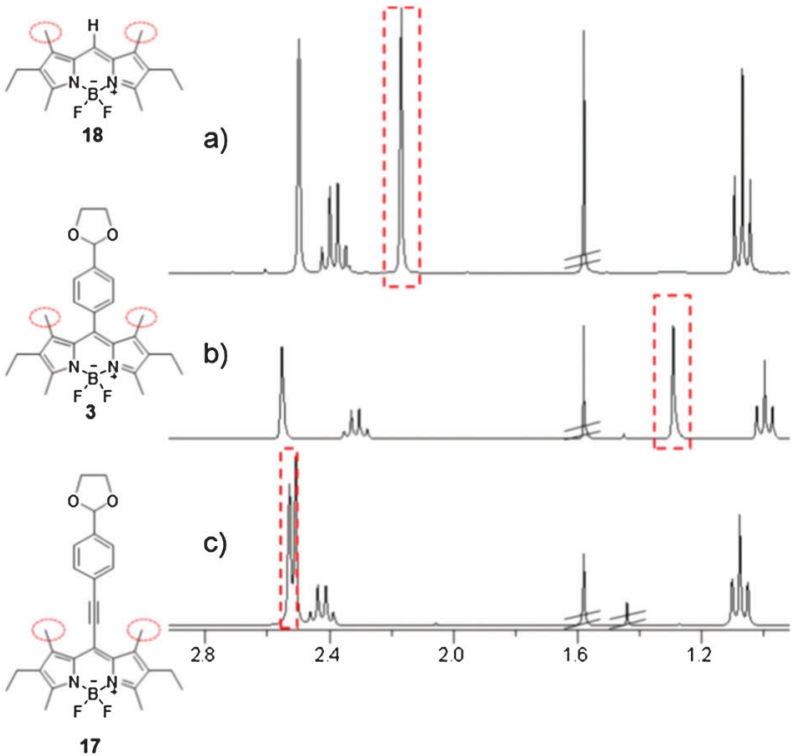

Fig. 1 Excerpts of the ${ }^{1} \mathrm{H}$-NMR spectra of (a) the meso-proton BODIPY 1,3,5,7tetramethyl-2,6-diethyl-4,4-difluoro-4-bora-3a,4a-diaza-s-indacene (18), (b) the mesophenyl BODIPY (3) and (c) the corresponding meso-ethynylphenyl BODIPY (17). The red boxes mark the resonance signal attributed to the 1,7-methyl protons. (The signals at 1.56 and $1.44 \mathrm{ppm}$ can be neglected because they arise from water and cyclohexane, respectively. The whole spectra are depicted in Fig. S7, ESIt.)

Further, the meso-phenyl group mainly affects the magnetic environment. In contrast, the meso-ethynyl bridge group is able to reduce the electron density at these positions through the conjugation. These observations are supported by the UV/vis measurements showing that the meso-ethynylphenyl BODIPY 17 causes a strong red shift due to the electron withdrawing ability of the meso-substituent whereas the corresponding mesophenyl BODIPY 3 shows hardly any difference in the absorption relative to the meso-proton BODIPY 18 (Fig. S10, ESI $\dagger$ ). However, the 3,5-methyl groups are only marginally influenced by the substituent at the meso-position.

Further, the stereochemistry of the vinyl bond between the BODIPY core and the donor group was investigated. On the basis of the ${ }^{1} \mathrm{H}-\mathrm{NMR}$ spectra of $\mathbf{8}$ and $\mathbf{1 6}$ (Fig. S4 and S5, ESI $\dagger$ ) the configuration can be clearly identified to be trans because the values for the vicinal ${ }^{3} J_{\mathrm{H} / \mathrm{H}}$ couplings are $16.6 \mathrm{~Hz}$ and 16.4 $\mathrm{Hz}$ for 8 and 16, respectively.

Finally, only the geometry of the 4-(2-carboxy-2-cyanovinyl)phenyl anchoring unit of 5, 8, 13 and 16 required assignment. Here, the carboxyl group can be oriented either cis or trans relative to the phenyl group. Since this group was attached in a comparable manner for all end-products and for 12 , we used ${ }^{13} \mathrm{C}-\mathrm{NMR}-$ analysis of $\mathbf{1 2}$ for the investigation of the orientation (see Fig. S9, ESI $\dagger$ ). The double bond geometry of $\mathbf{1 2}$ could be unambiguously assigned as trans. This is also supported by the results of Karas et $a .^{22}$ who investigated the crystal structure of a very similar compound (2-cyano-3-(4-hydroxyphenyl)acrylic acid).

\section{Optical properties}

The electronic absorption spectra of $5,8,13$ and 16 were recorded in solution and are depicted in Fig. 2a. Compound $\mathbf{5}$
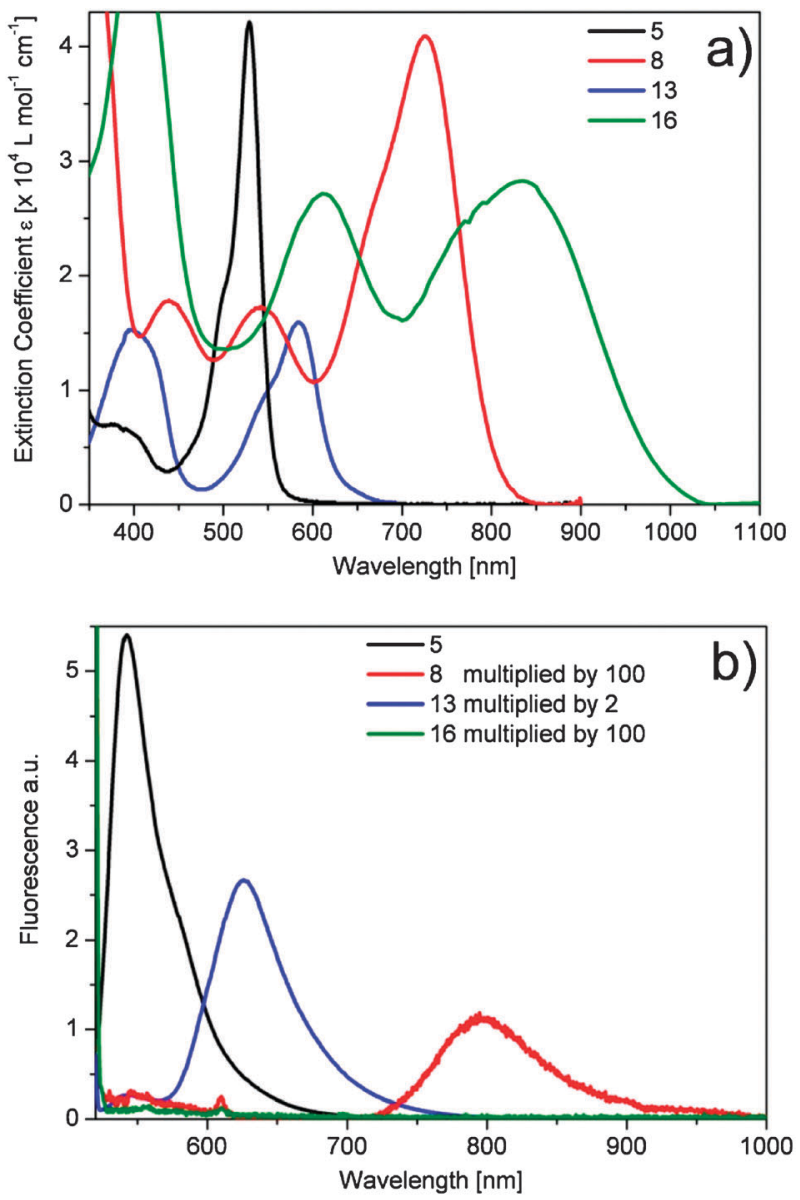

Fig. 2 (a) Electronic absorption spectra and (b) emission spectra of the BODIPYs 3 (in $\mathrm{CH}_{2} \mathrm{Cl}_{2}$ ), 8 (in $\mathrm{CH}_{2} \mathrm{Cl}_{2}$ ), 13 (in $\mathrm{CH}_{2} \mathrm{Cl}_{2}$ : THF $1: 1$ ) and 16 (in $\mathrm{CH}_{2} \mathrm{Cl}_{2}$ ) measured at a concentration in the range of $1 \times 10^{-5} \mathrm{M}$.

shows the typical BODIPY absorption with the sharp $\mathrm{S}_{0}-\mathrm{S}_{1}$ transition at $530 \mathrm{~nm}$ and a high extinction coefficient $(\varepsilon=$ $4.21 \times 10^{4} \mathrm{M}^{-1} \mathrm{~cm}^{-1}$ ). Additionally, a shoulder appears at $500 \mathrm{~nm}$ which is attributed to the $0-1$ vibrational transition. In comparison to that the $\mathrm{S}_{0}-\mathrm{S}_{1}$ transition of its mesoethynylphenyl derivative (13) is red-shifted by $55 \mathrm{~nm}$. The signal is broader and the extinction coefficient is reduced to $1.67 \times$ $10^{4} \mathrm{M}^{-1} \mathrm{~cm}^{-1}$. The $0-1$ vibrational transition was detected at $542 \mathrm{~nm}$. The reason for the reduced extinction coefficient of 13 compared to $\mathbf{5}$ is the larger spatial separation of the molecular orbitals involved in the transition. This is supported by DFT calculations (Fig. 3) which indicate an increased distance between HOMO and LUMO with the introduction of the meso-ethynyl unit. The larger distance lowers the transition probability. Thus, also the extinction coefficient is reduced. A further interesting feature of $\mathbf{1 3}$ is the absorption band at $397 \mathrm{~nm}$. The extinction coefficient of this band is much higher for $\mathbf{1 3}$ than for $\mathbf{5}$. We found that this band is associated with the meso-phenyl/ethynylphenyl unit. The pronounced band of $\mathbf{1 3}$ indicates that the electronic interaction between the BODIPY core and the meso-substituent can be increased by the mesoethynyl group. 
a)
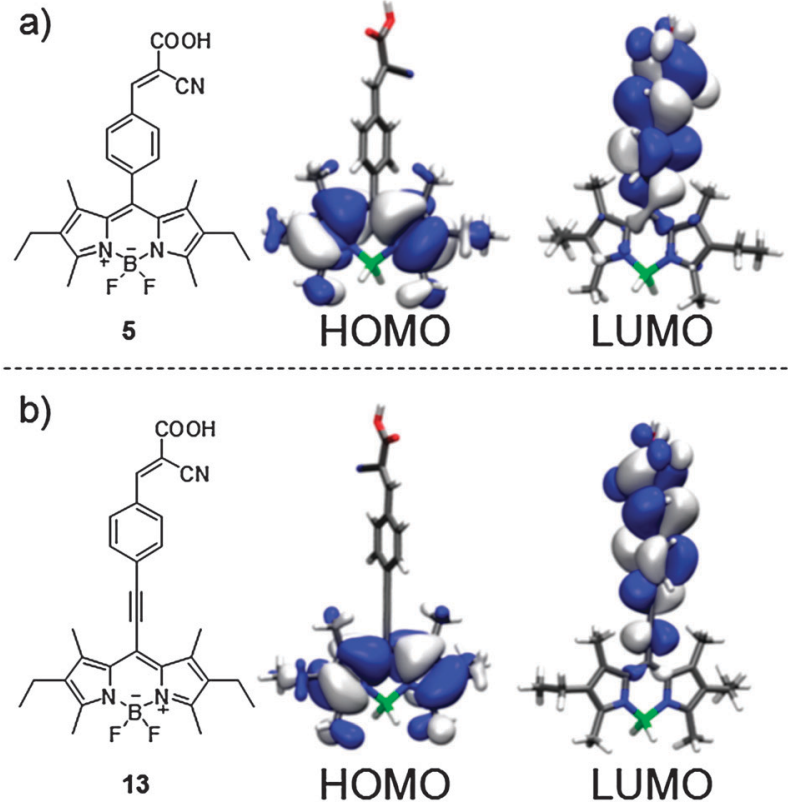

Fig. 3 Orbital maps of the HOMO and LUMO of (a) 5 and (b) 13.

With the attachment of the MeOTPA donor groups, the absorption spectra of $\mathbf{5}$ and $\mathbf{1 3}$ experience a strong bathochromic shift. The absorption edge of 8 was detected at $840 \mathrm{~nm}$ and that of 16 at $1030 \mathrm{~nm}$. The absorption maxima appear at $725 \mathrm{~nm}\left(\varepsilon=4.09 \times 10^{4} \mathrm{M}^{-1} \mathrm{~cm}^{-1}\right)$ and $835 \mathrm{~nm}(\varepsilon=2.83 \times$ $10^{4} \mathrm{M}^{-1} \mathrm{~cm}^{-1}$ ) for 8 and 16, respectively. These are excellent absorption ranges and extinction coefficients providing the possibility of improving the light harvesting of solar cells by using these dyes as sensitizers. It is important to note that the extinction coefficients of the MeOTPA-substituted BODIPYs are higher than $1 \times 10^{4} \mathrm{M}^{-1} \mathrm{~cm}^{-1}$ over the whole visible spectrum up to $787 \mathrm{~nm}$ and $940 \mathrm{~nm}$ for 8 and 16, respectively. This proves the excellent optical behaviour of BODIPYs carrying strong donor groups which is even more pronounced for meso-ethynylphenyl BODIPYs. The low energy bands of 8 and 16 can be attributed to intramolecular charge transfer.

To further investigate the influence of the ethynyl spacer and the donor substituents, steady-state emission measurements were done. Compared to $\mathbf{5}$, the emission of $\mathbf{1 3}$ was remarkably reduced by the introduction of the ethynyl spacer (Fig. 2b). The fluorescence quantum yields in solution are 2.18 and $1.69 \%$ for 5 and 13, respectively. For 8 and 16, the fluorescence was too weak to determine the fluorescence quantum yield reliably. Additionally, the Stokes shift of $\mathbf{1 3}\left(\Delta_{\text {Stokes }}=\right.$ $42 \mathrm{~nm})$ was more than thrice that of $5\left(\Delta_{\text {Stokes }}=12 \mathrm{~nm}\right)$. The explanation for both observations lies within the different freedom of rotation of the phenyl rings. ${ }^{16}$ The increased distance due to the ethynyl-bridge enables free rotation of the phenyl group around the axis given by the meso-spacer. In contrast, the meso-phenyl ring in $\mathbf{5}$ is restricted to an almost orthogonal position by the 1,7-dimethyl groups. Consequently, the emission probability of $\mathbf{1 3}$ is reduced via non-radiative decay due to the motion of the phenyl group. ${ }^{16}$ Additionally, the
Stokes shift of $\mathbf{1 3}$ is increased due to stronger structural rearrangement. For the MeOTPA-substituted BODIPYs 8 and 16, the fluorescence was very weak or even below the resolution of the spectrometer. This is attributed to a possible intramolecular charge transfer.

\section{Electrochemical properties and DFT calculations}

Cyclic voltammetry was used to examine the redox properties of the BODIPY dyes in solution. The energy levels of the final products are given in Table 1 . Cyclic voltammograms of 5, 8, 13 and 16 and the deprotected counterparts 4, 7, 11, and 15 as well as a table summarizing the redox values of all BODIPY derivatives are included in the ESI $\dagger$ (Fig. S11, S12, and Table S1).

In general, the BODIPY core and the donor substituent show a reversible behaviour, but on attaching the cyanocarboxylic acid group, the anodic and cathodic peak currents decrease. Therefore the peaks are less pronounced. In addition, a comparison of the calculated HOMO/LUMO energy levels of all compounds reveals two general trends: first, for all BODIPY compounds with methyl substituents, the only oxidation (denoted $E_{\mathrm{OX} 1}=\mathrm{HOMO}=-5.41 \pm 0.03 \mathrm{eV}$ ) is unaffected by the substituent at the meso-position (see Table 1 and Table S1, ESI $\dagger$ for all compounds). This value of the $E_{\mathrm{OX} 1}$ is thus assigned to the BODIPY core. It is also known from the literature that the HOMO of meso-phenyl BODIPY dyes without strong donor groups is delocalized over the BODIPY framework. ${ }^{16,23}$ Secondly, with increasing electron withdrawing ability of the meso-substituent, the energy level of the LUMO is shifted to lower values. Consequently, the LUMO is dependent on the meso-substituent.

These findings are supported by DFT calculations on $\mathbf{5}$ (meso-phenyl) and 13 (meso-ethynylphenyl) (see Fig. 3). The LUMO of $\mathbf{5}$ is delocalized over the phenyl group and the anchoring group. For 13, the LUMO is additionally distributed over the ethynyl-bridge. The delocalization of the LUMO over the meso-substituent is attributed to the strong electron withdrawing para-2-carboxy-2-cyanovinyl group. This is also in agreement with the literature. ${ }^{16}$

By the attachment of the MeOTPA-donor via a vinylic bond, the conjugated system is further extended. This can not only be seen in the absorption, but also in the cyclic voltammetry experiments.

The cyclic voltammograms of all MeOTPA-substituted BODIPYs show three reversible oxidation signals (Fig. S11 and S12, ESI $\dagger$ ).

Table 1 Summary of the energy levels calculated from cyclic voltammetry experiments measured at $50 \mathrm{mV} \mathrm{s}^{-1}$ in $\mathrm{CH}_{2} \mathrm{Cl}_{2}$ with $0.1 \mathrm{M}$ tetrabutylammonium hexafluorophosphate using ferrocene as reference

\begin{tabular}{lllll}
\hline Compound & $E_{\mathrm{OX} 1}{ }^{a}[\mathrm{eV}]$ & $E_{\mathrm{OX} 2}[\mathrm{eV}]$ & $E_{\mathrm{OX} 3}[\mathrm{eV}]$ & $E_{\mathrm{LUMO}}{ }^{b}[\mathrm{eV}]$ \\
\hline $\mathbf{5}$ & -5.40 & - & - & -3.18 \\
$\mathbf{1 3}$ & -5.44 & - & - & -3.48 \\
$\mathbf{8}$ & -4.84 & -4.97 & -5.42 & -3.28 \\
$\mathbf{1 6}$ & -4.84 & -4.98 & -5.43 & -3.59
\end{tabular}

${ }^{a} E_{\mathrm{OX} 1}$ is considered as the HOMO energy value. ${ }^{b}$ The LUMO levels were calculated from the optical band gap. 
The one at $-5.4 \mathrm{eV}$ arising from the BODIPY core as discussed above and the two lower lying peaks $(-4.84 \pm 0.01 \mathrm{eV},-4.97 \pm$ $0.01 \mathrm{eV}$ ) originate from the MeOTPA group. In fact, for nonconjugated systems, only one oxidation peak would be expected for the MeOTPA unit. However, we detected two reversible oxidations for the MeOTPA substituent. This is due to the conjugation of the MeOTPA-moieties through the BODIPY core. The oxidation of one donor unit influences the electronic surrounding of the second one due to the conjugation. ${ }^{24}$

A further characteristic of the BODIPY derivatives is their stability against repeated oxidation and reduction cycles. Even, the MeOTPA-substituted BODIPYs were stable during repeated electrochemical measurements because the paramethoxy groups of the donors inhibit radical coupling of the triphenylamines.

In a nutshell, the BODIPYs are redox stable, their LUMO level can be tuned by the meso-substituent and the HOMO level can be adjusted by the donor groups.

\section{Photocurrent generation}

To elucidate the potential of BODIPYs 5, 8, 13 and 16 as light harvesters, we prepared solid-state dye-sensitized solar cells with these sensitizers and measured the incident photon-tocurrent conversion efficiency (IPCE) for each sample (Fig. 4). The final IPCE values depend on the optimization of device structure and adaptation of HOMO/LUMO values of the hole transport material used. Here we tested the applicability of the dyes using a reference hole transport material, spiro-OMeTAD. In general, both $\mathbf{8}$ and $\mathbf{1 6}$ show broad photoaction spectra. A comparison between the performance of $\mathbf{5}$ and $\mathbf{1 3}$ shows that $\mathbf{1 3}$ carrying a meso-ethynyl substituent contributes to the current generation over a much broader region. In accordance with the absorption measurements, 5 generates current up to $600 \mathrm{~nm}$, whereas 13 contributes up to $700 \mathrm{~nm}$. Due to a mismatch in the energy levels of the MeOTPA-substituted BODIPYs 8 and 16 $\left(E_{\mathrm{OX} 1}=-4.84 \mathrm{eV}\right)$ relative to the hole transport material spiroOMeTAD $\left(E_{\mathrm{OX} 1}=-4.91 \mathrm{eV}\right),{ }^{25}$ the absolute IPCE values for 8 and 16 are low. Nevertheless, the IPCE measurements clearly show that BODIPYs 8 and 16 contribute to the current generation

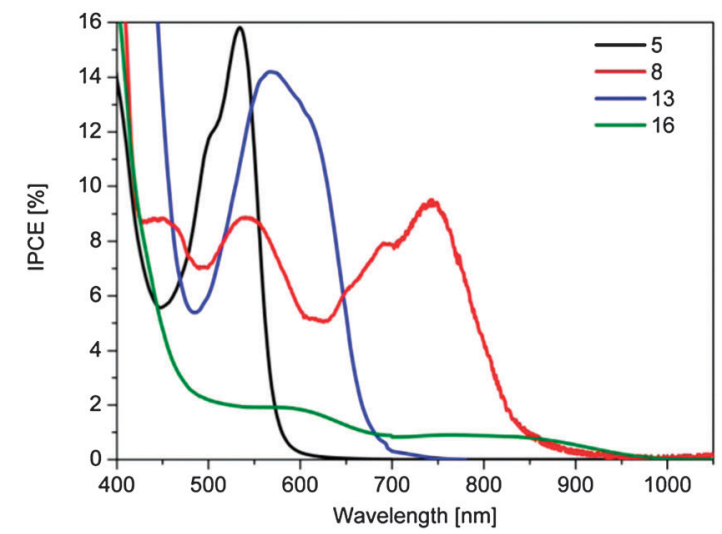

Fig. 4 IPCE-curves of solid-state dye-sensitized solar cells sensitized with BODIPYS 5, 8, 13 and 16 . over their entire absorption region; $\mathbf{8}$ and $\mathbf{1 6}$ generating photocurrent up to $900 \mathrm{~nm}$ and $1000 \mathrm{~nm}$, respectively. All the sensitizers provide a high potential for improvement by further optimization, e.g. by selecting suitable hole transport materials, tuning the thickness to match recombination and transport, etc.

\section{Conclusions}

We reported the tailor-made synthesis of novel BODIPY sensitizers capable of light harvesting and energy conversion in a broad range. The synthesis included the variation of the mesosubstituent (phenyl vs. ethynylphenyl) and the substituents at positions 3 and 5 (methyl vs. MeOTPA).

Investigations of the optical properties of 5, 8, 13 and 16 showed that the introduction of the ethynyl-bridge between the BODIPY core and the phenyl ring causes a strong bathochromic shift of the absorption (5 vs. 13 and 8 vs. 16). Further, a more than panchromatic behaviour resulted for both the mesophenyl and the meso-ethynylphenyl BODIPYs as a consequence of the attachment of MeOTPA-donor groups (8 and 16). In particular, 8 and 16 provide molar extinction coefficients higher than $1 \times 10^{4} \mathrm{M}^{-1} \mathrm{~cm}^{-1}$ over the whole UV/vis region and up to the near-IR part. 16 absorbs up to $1030 \mathrm{~nm}$ making this dye particularly interesting as sensitizers for solar cells.

Furthermore, cyclic voltammetry experiments showed that the HOMO level of the BODIPY depends solely on the donor unit regardless of the substituents at the meso-position. The measured HOMO levels were $-5.41 \pm 0.03 \mathrm{eV}$ and $-4.84 \pm 0.01 \mathrm{eV}$ for BODIPYs with methyl and MeOTPA donor groups, respectively. In contrast, the LUMO level depends on the mesosubstituent. Electron withdrawing substituents like the ethynyl group shift the level to lower values. The HOMO/LUMO distributions are further supported by DFT calculations.

IPCE measurements on solid-state dye-sensitized solar cells sensitized with BODIPYs 5, 8, 13 and 16 showed that the BODIPYs can contribute to the photocurrent generation over the entire absorption region.

\section{Experimental}

\section{General}

${ }^{1} \mathrm{H}$-NMR spectra were recorded on a Bruker Avance 300 spectrometer at a transmitter frequency of $300 \mathrm{MHz} .{ }^{1} \mathrm{H}-{ }^{13} \mathrm{C}$ coupled NMR spectra were recorded at a frequency of $125 \mathrm{MHz}$. The spectra were calibrated relative to the chemical shift of the respective solvent residual signal. The chemical shifts $(\delta)$ are given in ppm and the coupling constants $(J)$ in $\mathrm{Hz}$. UV/vis spectra were recorded in $\mathrm{CH}_{2} \mathrm{Cl}_{2}$ (or in THF : $\mathrm{CH}_{2} \mathrm{Cl}_{2} 1: 1$ for 13) on a Hitachi U-3000 spectrophotometer and in a Bentham DTR6 integrating sphere at a concentration in the range of $1 \times 10^{-5} \mathrm{M}$. The extinction coefficients $(\varepsilon)$ were calculated according to the Beer-Lambert law. Steady-state fluorescence measurements were performed on a JASCO Spectrofluorometer ST-8600. The slit width was $5 \mathrm{~nm}$ for excitation and emission. The photomultiplier voltage was $800 \mathrm{~V}$. For the determination of the fluorescence quantum yields, the area for the corrected 
emission spectra was divided by the corrected area of the absorbed light peak. The samples were excited at a wavelength $30 \mathrm{~nm}$ blue-shifted relative to the longest wavelength absorption maximum. Cyclic voltammetry was carried out under moistureand oxygen-free conditions using a standard three-electrode assembly connected to a potentiostat (model 263A, EG\&G Princeton Applied Research) at a scanning rate of $50 \mathrm{mV} \mathrm{s}^{-1}$. A Pt milli-electrode (model G0228, AMETEK Advanced Measurement Technology) was used as a working electrode. A platinum wire in the respective solvent plus conducting salt (tetrabutylammonium hexafluorophosphate, $0.1 \mathrm{M}$ ) was used as a counter electrode. The quasi-reference electrode consisted of an Ag-wire in an $\mathrm{AgNO}_{3}$ /acetonitrile solution (0.1 M). Each measurement was calibrated with the internal standard ferrocene/ferrocenium. The energy levels were determined using the empirical relation $E_{\mathrm{HOMO}}$ or LUMO $=\left[-\mathrm{e}\left(E^{1 / 2}\left(x\right.\right.\right.$ vs. $\left.\left.\left.\mathrm{Ag} / \mathrm{AgNO}_{3}\right)-E^{1 / 2}\left(\mathrm{Fc} / \mathrm{Fc}+v s . \mathrm{Ag} / \mathrm{AgNO}_{3}\right)\right)\right]-$ $4.80 \mathrm{eV}$. Molecular geometries, energy levels and orbitals were calculated from density functional theory at the B3LYP/cc-pVTZ level using the TURBOMOLE program package. ${ }^{26}$ Solid-state dye-sensitized solar cells were prepared according to a method reported elsewhere. ${ }^{27}$ IPCE spectra were recorded using a PVE300 photovoltaic device characterization system from Bentham.

\section{Synthesis}

4-(1,3-Dioxolan-2-yl)benzaldehyde (1), ${ }^{28}$ 8-[4-(1,3-dioxolan-2-yl)phenyl]-1,3,5,7-tetramethyl-2,6-diethyl-4,4-difluoro-4-bora-3a,4adiaza-s-indacene (3), ${ }^{14}$ 2-(4-iodophenyl)-1,3-dioxolane ${ }^{29}$ and 4-(di(4-methoxyphenyl)amino)benzaldehyde ${ }^{30}$ were prepared according to standard procedures. 1,3,5,7-Tetramethyl-2,6diethyl-4,4-difluoro-4-bora-3a,4a-diaza-s-indacene (18) was isolated during the synthesis of 10. Compounds $\mathbf{1 0}$ and $\mathbf{1 1}$ can also be synthesised according to ref. 31. 3-Ethyl-2,4-dimethyl-1 $H$-pyrrole and 3-trimethylsilylpropanal are commercially available. The syntheses of all other compounds are described below.

8-(4-Formylphenyl)-1,3,5,7-tetramethyl-2,6-diethyl-4,4-difluoro4-bora-3a,4a-diaza-s-indacene (4). $3(200.0 \mathrm{mg}, 0.463 \mathrm{mmol})$ is dissolved in THF $(50 \mathrm{~mL})$ and $5 \% \mathrm{HCl}_{\mathrm{aq}}(10 \mathrm{~mL})$ is added. The solution is stirred for $3.5 \mathrm{~h}$. Then $\mathrm{CH}_{2} \mathrm{Cl}_{2}(100 \mathrm{~mL})$ is added and the solution is washed with diluted $\mathrm{NaHCO}_{3 \mathrm{aq}}(50 \mathrm{~mL})$ and water $(4 \times 80 \mathrm{~mL})$ until neutrality. The organic phase is dried over $\mathrm{Na}_{2} \mathrm{SO}_{4}$, filtered and the solvent is removed under vacuum to yield the pure product. Yield: $189 \mathrm{mg}$ (red solid), $100 \%$. $\lambda_{\text {max }}(\mathrm{DCM}) / \mathrm{nm}=528\left(\varepsilon / \mathrm{M}^{-1} \mathrm{~cm}^{-1}=58300\right), 500 \mathrm{sh}(20481)$. FT-IR (ATR): $\nu_{\max } / \mathrm{cm}^{-1}=3361(\mathrm{w}), 2965(\mathrm{~m}), 1701(\mathrm{~m}), 1536(\mathrm{~s})$, $1470(\mathrm{~m}), 1405(\mathrm{~m}), 1317$ (s), $1262(\mathrm{~m}), 1184(\mathrm{~s}), 1052(\mathrm{~m})$, $974(\mathrm{~s}), 798(\mathrm{~m}) .{ }^{1} \mathrm{H}-\mathrm{NMR}\left(300 \mathrm{MHz}, \mathrm{CDCl}_{3}\right): \delta / \mathrm{ppm}=1.00$ $\left(\mathrm{t},{ }^{3} J_{1 \mathrm{H} / 1 \mathrm{H}}=7.53 \mathrm{~Hz}, 6 \mathrm{H}, 2 / 6-\mathrm{CH}_{2} \mathrm{CH}_{3}\right), 1.27\left(\mathrm{~s}, 6 \mathrm{H}, 1 / 7-\mathrm{CH}_{3}\right), 2.32$ (q, $\left.{ }^{3} J_{1 \mathrm{H} / 1 \mathrm{H}}=7.59 \mathrm{~Hz}, 4 \mathrm{H}, 2 / 6-\mathrm{CH}_{2} \mathrm{CH}_{3}\right), 2.56\left(\mathrm{~s}, 6 \mathrm{H}, 3 / 5-\mathrm{CH}_{3}\right)$, $7.53\left(\mathrm{~d},{ }^{3} J_{1 \mathrm{H} / 1 \mathrm{H}}=8.04 \mathrm{~Hz}, 2 \mathrm{H}, 8-H_{\mathrm{ar}}\right), 8.04\left(\mathrm{~d},{ }^{3} J_{1 \mathrm{H} / 1 \mathrm{H}}=8.25 \mathrm{~Hz}\right.$, $\left.2 \mathrm{H}, 8-H_{\mathrm{ar}}\right), 10.14(\mathrm{~s}, 1 \mathrm{H}, \mathrm{COH})$.

8-[4-(2-Carboxy-2-cyanovinyl)phenyl]-1,3,5,7-tetramethyl-2,6diethyl-4,4-difluoro-4-bora-3a,4a-diaza- $s$-indacene (5). 2-Cyanoacetic acid (218.7 mg, $2.572 \mathrm{mmol}, 7 \mathrm{eq}$.) and 4 (150.0 mg, $0.367 \mathrm{mmol}, 1 \mathrm{eq}$.$) are dissolved in dry acetonitrile (35 \mathrm{~mL})$ and piperidine $(50 \mu \mathrm{L})$ is added. Then, the solution is heated to reflux for $3 \mathrm{~h}$. The solvent is removed and the residue is dissolved in $\mathrm{CH}_{2} \mathrm{Cl}_{2}$ washed with water $(4 \times 80 \mathrm{~mL})$, dried over $\mathrm{Na}_{2} \mathrm{SO}_{4}$ and is concentrated. The raw product is purified by column chromatography with toluene : methanol $5: 1$ as eluent. Yield after freeze-drying from 1,4-dioxane: $158 \mathrm{mg}$ (red-orange solid, $R_{\mathrm{f}}\left(\mathrm{SiO}_{2} ;\right.$ toluene: methanol $\left.\left.5: 1\right)=0.20\right), \quad 90 \%$. $\lambda_{\max }(\mathrm{DCM}) / \mathrm{nm}=530\left(\varepsilon / \mathrm{M}^{-1} \mathrm{~cm}^{-1}=42137\right), 500 \mathrm{sh}(18610)$, 381 (6951). FT-IR (ATR): $\nu_{\max } / \mathrm{cm}^{-1}=3464$ (br), 2964 (w), 2223 (w) $1629(\mathrm{w}), 1539$ (s), $1629(\mathrm{~m}), 1470(\mathrm{~m}), 1393(\mathrm{~m}), 1187(\mathrm{~s}), 1057$ (m), $977(\mathrm{~s}), 708(\mathrm{~m}) .{ }^{1} \mathrm{H}-\mathrm{NMR}\left(300 \mathrm{MHz}, \mathrm{DMSO}_{6}\right): \delta / \mathrm{ppm}=0.94$ $\left(\mathrm{t},{ }^{3} J_{1 \mathrm{H} / 1 \mathrm{H}}=7.02 \mathrm{~Hz}, 6 \mathrm{H}, 2 / 6-\mathrm{CH}_{2} \mathrm{CH}_{3}\right), 1.28\left(\mathrm{~s}, 6 \mathrm{H}, 1 / 7-\mathrm{CH}_{3}\right), 2.27$ $\left(\mathrm{q},{ }^{3} J_{1 \mathrm{H} / 1 \mathrm{H}}=6.99 \mathrm{~Hz}, 4 \mathrm{H}, 2 / 6-\mathrm{CH}_{2} \mathrm{CH}_{3}\right), 2.44\left(\mathrm{~s}, 6 \mathrm{H}, 3 / 5-\mathrm{CH}_{3}\right), 7.57$ $\left(\mathrm{d},{ }^{3} J_{1 \mathrm{H} / 1 \mathrm{H}}=8.16 \mathrm{~Hz}, 2 \mathrm{H}, 8-H_{\mathrm{ar}}\right), 8.14\left(\mathrm{~d},{ }^{3} J_{1 \mathrm{H} / 1 \mathrm{H}}=8.07 \mathrm{~Hz}, 2 \mathrm{H}\right.$, $\left.8-H_{\mathrm{ar}}\right), 8.27(\mathrm{~s}, 1 \mathrm{H}, \mathrm{Ph}-\mathrm{CH}=\mathrm{C}(\mathrm{COOH})(\mathrm{CN}))$.

8-[4-(1,3-Dioxolan-2-yl)phenyl]-1,7-dimethyl-3,5-di[4-(di(p-methoxyphenyl)-amino)styryl]-2,6-diethyl-4,4-difluoro-4-bora3a,4a-diaza-s-indacene (6). To a solution of $3(100.0 \mathrm{mg}$, $0.221 \mathrm{mmol}, 1$ eq.) and 4-(di(4-methoxyphenyl)amino)-benzaldehyde (221.1 mg, $0.663 \mathrm{mmol}, 3$ eq.) in benzene $(20 \mathrm{~mL})$, piperidine $(0.3 \mathrm{~mL})$ and glacial acetic acid $(0.25 \mathrm{~mL})$ were added. After heating the solution to reflux over a glass frit containing molecular sieve ( $4 \AA$ ) for $11 \mathrm{~h}$, the solvent is removed and the raw product is purified by column chromatography using cyclohexane : ethyl acetate $2: 1$ as eluent. Yield: $77 \mathrm{mg}$ (greenblack solid, $R_{\mathrm{f}}\left(\mathrm{SiO}_{2}\right.$; cyclohexane : ethyl acetate $\left.\left.2: 1\right)=0.30\right)$, $32 \%$. $\lambda_{\max }(\mathrm{DCM}) / \mathrm{nm}=715\left(\varepsilon / \mathrm{M}^{-1} \mathrm{~cm}^{-1}=56444\right), 534$ (20179), 437 (21 739), 358 (50 498). FT-IR (ATR): $\nu_{\max } / \mathrm{cm}^{-1}=2962(\mathrm{w})$, $1587(\mathrm{~m}), 1503$ (s), 1441 (m), 1242 (s), $1174(\mathrm{~s}), 1028(\mathrm{~m}), 819(\mathrm{~m})$. ${ }^{1} \mathrm{H}-\mathrm{NMR}\left(300 \mathrm{MHz}, \mathrm{CDCl}_{3}\right): \delta / \mathrm{ppm}=1.15\left(\mathrm{t},{ }^{3} J_{1 \mathrm{H} / 1 \mathrm{H}}=7.50 \mathrm{~Hz}\right.$, $\left.6 \mathrm{H}, 2 / 6-\mathrm{CH}_{2} \mathrm{CH}_{3}\right), 1.32\left(\mathrm{~s}, 6 \mathrm{H}, 1 / 7-\mathrm{CH}_{3}\right) ; 2.61\left(\mathrm{q},{ }^{3} J_{1 \mathrm{H} / 1 \mathrm{H}}=\right.$ $\left.7.47 \mathrm{~Hz}, 4 \mathrm{H}, 2 / 6-\mathrm{CH}_{2} \mathrm{CH}_{3}\right), 3.83(\mathrm{~s}, 12 \mathrm{H}, \mathrm{OMe}), 4.09-4.26$ $\left(\mathrm{m}, 4 \mathrm{H}, \mathrm{O}-\mathrm{CH}_{2} \mathrm{CH}_{2}-\mathrm{O}\right), 5.90(\mathrm{~s}, 1 \mathrm{H}, \mathrm{Ph}-\mathrm{CH}), 6.86\left(\mathrm{~d},{ }^{3} J_{1 \mathrm{H} / 1 \mathrm{H}}=\right.$ $\left.8.97 \mathrm{~Hz}, 8 \mathrm{H}, 3 / 5-H_{\mathrm{ar}}\right), 6.93\left(\mathrm{~d},{ }^{3} J_{1 \mathrm{H} / 1 \mathrm{H}}=8.70 \mathrm{~Hz}, 4 \mathrm{H}, 3 / 5-H_{\mathrm{ar}}\right)$, $7.10\left(\mathrm{~d},{ }^{3} J_{1 \mathrm{H} / 1 \mathrm{H}}=8.94 \mathrm{~Hz}, 8 \mathrm{H}, 3 / 5-H_{\mathrm{ar}}\right), 7.19\left(\mathrm{~d},{ }^{3} J_{1 \mathrm{H} / 1 \mathrm{H}}=\right.$ $16.71 \mathrm{~Hz}, 2 \mathrm{H} ; 3 / 5 \mathrm{CH}=\mathrm{CH}), 7.36\left(\mathrm{~d},{ }^{3} J_{1 \mathrm{H} / 1 \mathrm{H}}=8.07 \mathrm{~Hz}, 2 \mathrm{H}\right.$, $\left.8-H_{\mathrm{ar}}\right), 7.42\left(\mathrm{~d},{ }^{3} J_{1 \mathrm{H} / 1 \mathrm{H}}=8.73 \mathrm{~Hz}, 4 \mathrm{H}, 3 / 5-H_{\mathrm{ar}}\right), 7.64(\mathrm{~d}+\mathrm{d}$, $\left.{ }^{3} J_{1 \mathrm{H} / 1 \mathrm{H}}=8.22 \mathrm{~Hz}, 2 \mathrm{H}+2 \mathrm{H}, 3 / 5 \mathrm{CH}=\mathrm{CH}+8-H_{\mathrm{ar}}\right)$.

8-(4-Formylphenyl)-1,7-dimethyl-3,5-di[4-(di( $p$-methoxy-phenyl)amino)-styryl]-2,6-diethyl-4,4-difluoro-4-bora-3a,4a-diaza-s-indacene (7). $6(100.0 \mathrm{mg}, 0.092 \mathrm{mmol})$ is dissolved in THF $(40 \mathrm{~mL})$ and $5 \% \mathrm{HCl}_{\mathrm{aq}}(5 \mathrm{~mL})$ is added. The solution is stirred overnight. Then $\mathrm{CH}_{2} \mathrm{Cl}_{2}(100 \mathrm{~mL})$ is added and the solution is washed with diluted $\mathrm{NaHCO}_{3 \mathrm{aq}}(50 \mathrm{~mL})$ and water $(4 \times 100 \mathrm{~mL})$ until neutrality. The organic phase is dried over $\mathrm{Na}_{2} \mathrm{SO}_{4}$, filtered and the solvent is removed under vacuum to yield the pure product. Yield: $95 \mathrm{mg}$ (green-black solid), 99\%. $\lambda_{\max }(\mathrm{DCM}) / \mathrm{nm}=$ $723\left(\varepsilon / \mathrm{M}^{-1} \mathrm{~cm}^{-1}=55388\right), 545$ (21318), 440 (21318), 360 (51 403). FT-IR (ATR): $\nu_{\max } / \mathrm{cm}^{-1}=2961(\mathrm{w}), 1705(\mathrm{w}), 1590(\mathrm{~m}), 1502(\mathrm{~s})$, 1440 (m), 1240 (m), 1171 (m), 1035 (m), 822 (m). ${ }^{1} \mathrm{H}-\mathrm{NMR}(300 \mathrm{MHz}$, $\left.\mathrm{CDCl}_{3}\right): \delta / \mathrm{ppm}=1.16\left(\mathrm{t},{ }^{3} J_{1 \mathrm{H} / 1 \mathrm{H}}=7.32 \mathrm{~Hz}, 6 \mathrm{H}, 2 / 6-\mathrm{CH}_{2} \mathrm{CH}_{3}\right), 1.30$ $\left(\mathrm{s}, 6 \mathrm{H}, 1 / 7-\mathrm{CH}_{3}\right), 2.61\left(\mathrm{q},{ }^{3} J_{1 \mathrm{H} / 1 \mathrm{H}}=7.35 \mathrm{~Hz}, 4 \mathrm{H} ; 2 / 6-\mathrm{CH}_{2} \mathrm{CH}_{3}\right), 3.83$ $(\mathrm{s}, 12 \mathrm{H}, \mathrm{OMe}), 6.87\left(\mathrm{~d},{ }^{3} J_{1 \mathrm{H} / 1 \mathrm{H}}=8.94 \mathrm{~Hz}, 8 \mathrm{H}, 3 / 5-H_{\mathrm{ar}}\right), 6.93(\mathrm{~d}$, $\left.J_{1 \mathrm{H} / 1 \mathrm{H}}=8.67 \mathrm{~Hz}, 4 \mathrm{H}, 3 / 5-H_{\mathrm{ar}}\right), 7.10\left(\mathrm{~d},{ }^{3} J_{1 \mathrm{H} / 1 \mathrm{H}}=8.94 \mathrm{~Hz}, 8 \mathrm{H}\right.$, $\left.3 / 5-H_{\mathrm{ar}}\right), 7.20\left(\mathrm{~d},{ }^{3} J_{1 \mathrm{H} / 1 \mathrm{H}}=16.66 \mathrm{~Hz}, 2 \mathrm{H}, 3 / 5 \mathrm{CH}=\mathrm{CH}\right), 7.45(\mathrm{~d}$, $\left.{ }^{3} J_{1 \mathrm{H} / 1 \mathrm{H}}=8.67 \mathrm{~Hz}, 4 \mathrm{H}, 3 / 5-H_{\mathrm{ar}}\right), 7.55\left(\mathrm{~d},{ }^{3} J_{1 \mathrm{H} / 1 \mathrm{H}}=8.01 \mathrm{~Hz}, 2 \mathrm{H}, 8-H_{\mathrm{ar}}\right)$, $7.64\left(\mathrm{~d},{ }^{3} J_{1 \mathrm{H} / 1 \mathrm{H}}=16.54 \mathrm{~Hz}, 2 \mathrm{H}, 3 / 5 \mathrm{CH}=\mathrm{CH}\right), 8.04\left(\mathrm{~d},{ }^{3} J_{1 \mathrm{H} / 1 \mathrm{H}}=\right.$ $\left.8.07 \mathrm{~Hz}, 2 \mathrm{H}, 8-H_{\mathrm{ar}}\right), 10.15(\mathrm{~s}, 1 \mathrm{H}, \mathrm{COH})$. 
8-[4-(2-Carboxy-2-cyanovinyl)phenyl]-1,7-dimethyl-3,5-di[4-(di(p-methoxy-phenyl)amino)styryl]-2,6-diethyl-4,4-difluoro4-bora-3a,4a-diaza-s-indacene (8). 2-Cyanoacetic acid (65.6 mg, $0.772 \mathrm{mmol}, 7$ eq.) and 7 (114.3 $\mathrm{mg}, 0.110 \mathrm{mmol}, 1 \mathrm{eq}$.$) are$ dissolved in dry acetonitrile $(35 \mathrm{~mL})$ and three drops of piperidine are added. Then, the solution is heated to reflux for $5 \mathrm{~h}$. The solvent is removed and the residue is dissolved in $\mathrm{CH}_{2} \mathrm{Cl}_{2}$, washed with water $(4 \times 80 \mathrm{~mL})$, dried over $\mathrm{Na}_{2} \mathrm{SO}_{4}$ and the solvent is removed under vacuum. The raw product is purified by column chromatography with $\mathrm{CH}_{2} \mathrm{Cl}_{2}$ : methanol 15:1 as eluent. Yield after freeze-drying from 1,4-dioxane: $72 \mathrm{mg}$ (brown-black solid, $R_{\mathrm{f}}\left(\mathrm{SiO}_{2} ; \mathrm{CH}_{2} \mathrm{Cl}_{2}\right.$ : methanol $\left.\left.15: 1\right)=0.45\right)$, $59 \% . \lambda_{\max }(\mathrm{DCM}) / \mathrm{nm}=725\left(\varepsilon / \mathrm{M}^{-1} \mathrm{~cm}^{-1}=40889\right), 543$ (17 258), 439 (17 846), 358 (48 342). FT-IR (ATR): $\nu_{\max } / \mathrm{cm}^{-1}=3405$ (br), 2963 (w), 2222 (w), 1593 (m), 1503 (s), 1440 (m), 1332 (m), 1241 (s), 1171 (s), 1034 (m), 823 (m). ${ }^{1} \mathrm{H}-\mathrm{NMR}$ (300 MHz, DMSO-d 6 ): $\delta / \mathrm{ppm}=1.07\left(\mathrm{t},{ }^{3} J_{1 \mathrm{H} / 1 \mathrm{H}}=7.26 \mathrm{~Hz}, 6 \mathrm{H}, 2 / 6-\mathrm{CH}_{2} \mathrm{CH}_{3}\right), 1.31(\mathrm{~s}, 6 \mathrm{H}$; $\left.1 / 7-\mathrm{CH}_{3}\right), 2.58\left(\mathrm{q},{ }^{3} \mathrm{~J}_{1 \mathrm{H} / 1 \mathrm{H}}=6.75 \mathrm{~Hz}, 4 \mathrm{H} ; 2 / 6-\mathrm{CH}_{2} \mathrm{CH}_{3}\right), 3.76$ $(\mathrm{s}, 12 \mathrm{H}, \mathrm{OMe}), 6.78\left(\mathrm{~d},{ }^{3} J_{1 \mathrm{H} / 1 \mathrm{H}}=8.73 \mathrm{~Hz}, 4 \mathrm{H}, 3 / 5-H_{\mathrm{ar}}\right), 6.93$ $\left(\mathrm{d},{ }^{3} J_{1 \mathrm{H} / 1 \mathrm{H}}=9.00 \mathrm{~Hz}, 8 \mathrm{H}, 3 / 5-H_{\mathrm{ar}}\right), 7.07\left(\mathrm{~d},{ }^{3} J_{1 \mathrm{H} / 1 \mathrm{H}}=8.94 \mathrm{~Hz}, 8 \mathrm{H}\right.$, $\left.3 / 5-H_{\mathrm{ar}}\right), 7.21\left(\mathrm{~d},{ }^{3} J_{1 \mathrm{H} / 1 \mathrm{H}}=16.59 \mathrm{~Hz}, 2 \mathrm{H}, 3 / 5 \mathrm{CH}=\mathrm{CH}\right), 7.41$ $\left(\mathrm{d},{ }^{3} J_{1 \mathrm{H} / 1 \mathrm{H}}=16.65 \mathrm{~Hz}, 2 \mathrm{H},+\mathrm{d}, 4 \mathrm{H},{ }^{3} J_{1 \mathrm{H} / 1 \mathrm{H}}=8.85 \mathrm{~Hz}, 3 / 5 \mathrm{CH}=\mathrm{CH}\right.$ $\left.+3 / 5-H_{\mathrm{ar}}\right), 7.56\left(\mathrm{~d},{ }^{3} J_{1 \mathrm{H} / 1 \mathrm{H}}=8.22 \mathrm{~Hz}, 2 \mathrm{H}, 8-H_{\mathrm{ar}}\right), 8.10\left(\mathrm{~d},{ }^{3} J_{1 \mathrm{H} / 1 \mathrm{H}}=\right.$ $\left.8.37 \mathrm{~Hz}, 2 \mathrm{H}, 8-H_{\mathrm{ar}}\right), 8.16(\mathrm{~s}, 1 \mathrm{H}, \mathrm{Ph}-\mathrm{C} H=\mathrm{C}(\mathrm{COOH})(\mathrm{CN}))$.

8-[(Trimethylsilyl)ethynyl]-1,3,5,7-tetramethyl-2,6-diethyl-4,4difluoro-4-bora-3a,4a-diaza-s-indacene (10). Under dry conditions, 3-ethyl-2,4-dimethyl-1 $H$-pyrrole (13.664 g, $110.909 \mathrm{mmol}$, 2 eq.) is dissolved in dry $\mathrm{CH}_{2} \mathrm{Cl}_{2}(300 \mathrm{~mL})$, cooled to $-5{ }^{\circ} \mathrm{C}$ and degassed with argon for $30 \mathrm{~min}$. Then 3-trimethylsilylpropanal (7.000 g, $55.454 \mathrm{mmol}, 1 \mathrm{eq}$.) and one drop of trifluoroacetic acid are added. The solution instantly becomes orange, and changes the colour firstly to red and then to deep violet. After $1 \mathrm{~h}$ 2,3-dichloro-5,6-dicyano-1,4-benzoquinone (12.588 g, $55.454 \mathrm{mmol}, 1$ eq.) is added at RT and stirring is continued overnight. $\mathrm{NEt}_{3}(46.4 \mathrm{~mL}, 332.726 \mathrm{mmol}, 6$ eq.) and $30 \mathrm{~min}$ later $\mathrm{BF}_{3} \cdot \mathrm{OEt}_{2}$ (55.7 mL, $443.635 \mathrm{mmol}, 8 \mathrm{eq}$.) are added slowly. Stirring is continued for further $3 \mathrm{~h}$. Then the solvent is removed under reduced pressure and the raw product is purified by column chromatography using cyclohexane : ethyl acetate $13: 1$ as eluent. Yield: $9.66 \mathrm{~g}$ (pink-black solid, $R_{\mathrm{f}}\left(\mathrm{SiO}_{2}\right.$; cyclohexane : ethyl acetate $13: 1)=0.49), 44 \% . \lambda_{\max }(\mathrm{DCM}) / \mathrm{nm}=$ $574\left(\varepsilon / \mathrm{M}^{-1} \mathrm{~cm}^{-1}=49206\right), 537 \mathrm{sh}$ (22 374), 360 (12 028), 274 (23 552). FT-IR (ATR): $\nu_{\max } / \mathrm{cm}^{-1}=2963(\mathrm{w}), 1533(\mathrm{~m}), 1455(\mathrm{~m})$, $1311(\mathrm{~m}), 1181(\mathrm{~m}), 1072(\mathrm{~m}), 971$ (m), 843 (m), 751 (m). ${ }^{1} \mathrm{H}-\mathrm{NMR}\left(300 \mathrm{MHz}, \mathrm{CDCl}_{3}\right): \delta / \mathrm{ppm}=0.31\left(\mathrm{~s}, 9 \mathrm{H}, \mathrm{Si}(\mathrm{CH})_{3}\right), 1.06$ $\left(\mathrm{t},{ }^{3} J_{1 \mathrm{H} / 1 \mathrm{H}}=7.53 \mathrm{~Hz}, 6 \mathrm{H}, 2 / 6-\mathrm{CH}_{2} \mathrm{CH}_{3}\right), 2.41\left(\mathrm{~s}, 6 \mathrm{H}, 1 / 7-\mathrm{CH}_{3}\right), 2.41$ (q, $\left.{ }^{3} J_{1 \mathrm{H} / 1 \mathrm{H}}=7.56 \mathrm{~Hz}, 4 \mathrm{H}, 2 / 6-\mathrm{CH}_{2} \mathrm{CH}_{3}\right), 2.51\left(\mathrm{~s}, 6 \mathrm{H} ; 3 / 5-\mathrm{CH}_{3}\right)$.

8-Ethynyl-1,3,5,7-tetramethyl-2,6-diethyl-4,4-difluoro-4-bora3a,4a-diaza-s-indacene (11). 10 ( $400.0 \mathrm{mg}, 0.999 \mathrm{mmol}, 1 \mathrm{eq}$.) is dissolved in methanol $(80 \mathrm{~mL}), \mathrm{KF}(290.2 \mathrm{mg}, 4.995 \mathrm{mmol}$, 5 eq.) is added and the reaction solution is stirred for $1.5 \mathrm{~h}$ at RT. After full consumption of the starting material, $1 \%$ $\mathrm{CH}_{3} \mathrm{COOH}_{\mathrm{aq}}(50 \mathrm{~mL})$ is added. Then, $\mathrm{CH}_{2} \mathrm{Cl}_{2}(150 \mathrm{~mL})$ is added and the organic layer is washed with water $(4 \times 80 \mathrm{~mL})$ until neutrality. It is dried over $\mathrm{Na}_{2} \mathrm{SO}_{4}$ and the solvent is removed under vacuum. Yield: $327 \mathrm{mg}$ (pink-black solid), 100\%. $\lambda_{\max }(\mathrm{DCM}) / \mathrm{nm}=572\left(\varepsilon / \mathrm{M}^{-1} \mathrm{~cm}^{-1}=59850\right), 534 \mathrm{sh}(26194)$, 352 (8205), 265 (21775) FT-IR (ATR): $\nu_{\max } / \mathrm{cm}^{-1}=3263(\mathrm{~m})$, 2960 (m), 2107 (m), 1535 (m), 1456 (m), 1394 (m), 1311 (m), 1264 (m), 1187 (m), 1041 (s), 970 (s), 754 (m). ${ }^{1} \mathrm{H}-\mathrm{NMR}$ $\left(300 \mathrm{MHz}, \mathrm{CDCl}_{3}\right): \delta / \mathrm{ppm}=1.07\left(\mathrm{t},{ }^{3} J_{1 \mathrm{H} / 1 \mathrm{H}}=7.53 \mathrm{~Hz}, 6 \mathrm{H}\right.$, 2/6- $\mathrm{CH}_{2} \mathrm{CH}_{3}$ ), 2.41 (s, 6H, 1/7- $\left.\mathrm{CH}_{3}\right), 2.41$ (q, ${ }^{3} J_{1 \mathrm{H} / 1 \mathrm{H}}=7.56 \mathrm{~Hz}$, $\left.4 \mathrm{H}, 2 / 6-\mathrm{CH}_{2} \mathrm{CH}_{3}\right), 2.52\left(\mathrm{~s}, 6 \mathrm{H}, 3 / 5-\mathrm{CH}_{3}\right), 3.89$ (s, $\left.1 \mathrm{H}, \equiv H\right)$.

2-Cyano-3-(4-iodophenyl)acrylic acid (12). Under dry conditions, 4-iodobenzaldehyde (7.400 g, $31.894 \mathrm{mmol}, 1 \mathrm{eq.})$ is dissolved in benzene $(90 \mathrm{~mL})$. Piperidine $(0.90 \mathrm{~mL})$, glacial acetic acid $(0.75 \mathrm{~mL})$ and 2-cyanoacetic acid (18.990 g, $0.223 \mathrm{~mol}$, 7 eq.) are added. The solution is heated to reflux over a glass frit containing molecular sieve ( $4 \AA$ ) for $40 \mathrm{~h}$. Then, the solvent is removed and the raw product is purified by repetitive recrystallisation from $\mathrm{CH}_{2} \mathrm{Cl}_{2}$. Yield: $5.03 \mathrm{~g}$ (white solid), 53\%. FT-IR (ATR): $\nu_{\max } / \mathrm{cm}^{-1}=3312(\mathrm{br}), 2222(\mathrm{~m}), 1623$ (s), 1578 (s), 1481 (m), 1387 (s), 1187 (w), 1058 (m), 1005 (s), 817 (s), 781 (m). ${ }^{1} \mathrm{H}-\mathrm{NMR}\left(300 \mathrm{MHz}\right.$, DMSO-d $\left.{ }_{6}\right): \delta / \mathrm{ppm}=7.79\left(\mathrm{~d},{ }^{3} J_{1 \mathrm{H} / 1 \mathrm{H}}=\right.$ $\left.8.52 \mathrm{~Hz}, 2 \mathrm{H}, 2-H_{\mathrm{ar}}\right), 7.98\left(\mathrm{~d},{ }^{3} J_{1 \mathrm{H} / 1 \mathrm{H}}=8.46 \mathrm{~Hz}, 2 \mathrm{H}, 3-H_{\mathrm{ar}}\right), 8.30$ (s, $1 \mathrm{H}, \mathrm{Ph}-\mathrm{CH}=\mathrm{C}(\mathrm{COOH})(\mathrm{CN})), 14.04$ (s (broad), $1 \mathrm{H}, \mathrm{COOH})$. ${ }^{13} \mathrm{C}-\mathrm{NMR}\left(125 \mathrm{MHz}, \mathrm{DMSO}-\mathrm{d}_{6}\right): \delta=163.19\left(\mathrm{~d},{ }^{3} J_{1 \mathrm{H} / 13 \mathrm{C}}=6.7 \mathrm{~Hz}\right.$, $\mathrm{COOH}), 153.46\left(\mathrm{~d},{ }^{1} J_{1 \mathrm{H} / 13 \mathrm{C}}=162.2 \mathrm{~Hz}, \mathrm{CH}=\mathrm{C}(\mathrm{COOH})(\mathrm{CN})\right)$, $138.29\left(\mathrm{~d},{ }^{1} J_{1 \mathrm{H} / 13 \mathrm{C}}=167.6 \mathrm{~Hz}, 3 / 5-C_{\mathrm{ar}}\right), 132.06\left(\mathrm{~d},{ }^{1} J_{1 \mathrm{H} / 13 \mathrm{C}}=162.8 \mathrm{~Hz}\right.$, 2/6- $C_{\text {ar }}$ ), $130.91\left(\mathrm{~s}, 1-C_{\mathrm{ar}}\right), 115.97\left(\mathrm{~d},{ }^{3} J_{1 \mathrm{H} / 13 \mathrm{C}}=13.9 \mathrm{~Hz}, C \mathrm{~N}\right), 104.43$ $(\mathrm{s}, \mathrm{CH}=C(\mathrm{COOH})(\mathrm{CN})), 101.50\left(\mathrm{~s}, 4-C_{\mathrm{ar}}\right)$.

8-[(4-(2-Carboxy-2-cyanovinyl)phenyl)ethynyl]-1,3,5,7-tetramethyl2,6-diethyl-4,4-difluoro-4-bora-3a,4a-diaza-s-indacene (13). Under dry and oxygen-free conditions, $12(820.0 \mathrm{mg}, 2.742 \mathrm{mmol}$, 3 eq.), $\mathrm{Pd}\left(\mathrm{PPh}_{3}\right)_{4}$ (63.4 mg, $0.055 \mathrm{mmol}, 0.06$ eq.), $\mathrm{CuI}$ (6.9 mg, $0.036 \mathrm{mmol}, 0.04$ eq.) and $\mathrm{NEt}_{3}(0.60 \mathrm{~mL}, 4.296 \mathrm{mmol}, 4.7$ eq.) are dissolved in dry THF (13 mL). Then, 11 (300.0 mg, $0.914 \mathrm{mmol}, 1$ eq.) is dissolved in dry THF $(20 \mathrm{~mL})$ and added dropwise over $3 \mathrm{~h}$ at RT to the reaction solution. After further 60 min stirring at RT, the solvent is removed. The residue is dissolved in $\mathrm{CHCl}_{3}$ and washed with water $(4 \times 100 \mathrm{~mL})$. The organic fraction is dried over $\mathrm{Na}_{2} \mathrm{SO}_{4}$ and filtered. After removal of the solvent, the raw product is purified by column chromatography with cyclohexane:ethyl acetate $2: 1+1 \%$ of glacial acetic acid, then the solvent is changed to $\mathrm{CH}_{2} \mathrm{Cl}_{2}$ followed by a change to $\mathrm{CH}_{2} \mathrm{Cl}_{2}$ : methanol 20:1 with a gradient to $10: 1$. Yield: $218 \mathrm{mg}$ (purple-black solid, $R_{\mathrm{f}}\left(\mathrm{SiO}_{2} ; \mathrm{CH}_{2} \mathrm{Cl}_{2}\right.$ : methanol $10: 1)=0.50), 48 \% . \lambda_{\max }(\mathrm{DCM}:$ THF $1: 1) / \mathrm{nm}=585\left(\varepsilon / \mathrm{M}^{-1} \mathrm{~cm}^{-1}=\right.$ $16708), 542 \mathrm{sh}$ (9628), 397 (16 047), 279 (21144). FT-IR (ATR): $\nu_{\max } / \mathrm{cm}^{-1}=3403(\mathrm{br}), 2963(\mathrm{w}), 2214(\mathrm{w}), 1631(\mathrm{w}), 1539(\mathrm{~m})$, $1472(\mathrm{~m}), 1392(\mathrm{~m}), 1321$ (m), 1194 (s), 1043 (m), 977 (s), $801(\mathrm{~m}), 754(\mathrm{~m}) .{ }^{1} \mathrm{H}-\mathrm{NMR}\left(300 \mathrm{MHz}, \mathrm{DMF}_{-}\right.$) $): \delta / \mathrm{ppm}=1.07$ $\left(\mathrm{t},{ }^{3} J_{1 \mathrm{H} / 1 \mathrm{H}}=7.38 \mathrm{~Hz}, 6 \mathrm{H}, 2 / 6-\mathrm{CH}_{2} \mathrm{CH}_{3}\right), 2.46\left(\mathrm{q},{ }^{3} J_{1 \mathrm{H} / 1 \mathrm{H}}=7.53 \mathrm{~Hz}\right.$, $\left.4 \mathrm{H}, 2 / 6-\mathrm{CH}_{2} \mathrm{CH}_{3}\right), 2.53\left(\mathrm{~s}, 6 \mathrm{H}, 3 / 5-\mathrm{CH}_{3}\right), 2.58\left(\mathrm{~s}, 6 \mathrm{H}, 1 / 7-\mathrm{CH}_{3}\right)$, $7.87\left(\mathrm{~d},{ }^{3} J_{1 \mathrm{H} / 1 \mathrm{H}}=8.34 \mathrm{~Hz}, 2 \mathrm{H}, 8-H_{\mathrm{ar}}\right), 8.09\left(\mathrm{~d},{ }^{3} J_{1 \mathrm{H} / 1 \mathrm{H}}=8.28 \mathrm{~Hz}\right.$, $\left.2 \mathrm{H}, 8-H_{\mathrm{ar}}\right), 8.29(\mathrm{~s}, 1 \mathrm{H}, \mathrm{Ph}-\mathrm{CH}=\mathrm{C}(\mathrm{COOH})(\mathrm{CN}))$.

8-[(Trimethylsilyl)ethynyl]-1,7-dimethyl-3,5-di[4-(di(p-methoxyphenyl)-amino)styryl]-2,6-diethyl-4,4-difluoro-4-bora-3a,4a-diaza$\boldsymbol{s}$-indacene (14). Under dry conditions, 4-(di(4-methoxyphenyl)amino)benzaldehyde ( $1.873 \mathrm{~g}, 5.620 \mathrm{mmol}, 3 \mathrm{eq}$.) is dissolved in dry benzene $(40 \mathrm{~mL})$. Piperidine $(0.30 \mathrm{~mL})$, glacial acetic acid $(0.25 \mathrm{~mL})$ and finally 10 (750.0 mg, $1.873 \mathrm{mmol}, 1$ eq.) are added. 
The reaction solution is heated to reflux over a glass frit containing molecular sieve $(4 \AA)$ to remove the formed water. After complete consumption of the staring material $(21 \mathrm{~h})$, the solvent is removed and the raw product is purified by column chromatography using $\mathrm{CH}_{2} \mathrm{Cl}_{2}$ : hexane 9:1 as eluent. Yield: $800 \mathrm{mg}$ (blue-black solid, $R_{\mathrm{f}}\left(\mathrm{SiO}_{2} ; \mathrm{CH}_{2} \mathrm{Cl}_{2}\right.$ : hexane 9:1) = 0.23), $41 \% . \lambda_{\max }(\mathrm{DCM}) / \mathrm{nm}=784\left(\varepsilon / \mathrm{M}^{-1} \mathrm{~cm}^{-1}=62815\right), 582(28346)$, 465 (17 482), 381 (60 544). FT-IR (ATR): $\nu_{\max } / \mathrm{cm}^{-1}=2959(\mathrm{w})$, 2148 (w), 1587 (m), 1497 (s), 1440 (m), 1237 (m), 1161 (m), 1029 (m), $818(\mathrm{~m}) .{ }^{1} \mathrm{H}-\mathrm{NMR}\left(300 \mathrm{MHz}\right.$, benzene-d $\left.{ }_{6}\right): \delta / \mathrm{ppm}=0.22$ $\left(\mathrm{s}, 9 \mathrm{H}, \mathrm{Si}(\mathrm{CH})_{3}\right), 1.07\left(\mathrm{t},{ }^{3} \mathrm{~J}_{1 \mathrm{H} / 1 \mathrm{H}}=7.29 \mathrm{~Hz}, 6 \mathrm{H}, 2 / 6-\mathrm{CH}_{2} \mathrm{CH}_{3}\right), 2.36$ $\left(\mathrm{s}, 6 \mathrm{H}, 1 / 7-\mathrm{CH}_{3}\right), 2.55\left(\mathrm{q},{ }^{3} \mathrm{~J}_{1 \mathrm{H} / 1 \mathrm{H}}=7.38 \mathrm{~Hz}, 4 \mathrm{H}, 2 / 6-\mathrm{CH}_{2} \mathrm{CH}_{3}\right)$, $3.37(\mathrm{~s}, 12 \mathrm{H}, \mathrm{OMe}), 6.75\left(\mathrm{~d},{ }^{3} J_{1 \mathrm{H} / 1 \mathrm{H}}=9.00 \mathrm{~Hz}, 8 \mathrm{H}, 3 / 5-H_{\mathrm{ar}}\right), 6.84$ $\left(\mathrm{d},{ }^{3} J_{1 \mathrm{H} / 1 \mathrm{H}}=8.70 \mathrm{~Hz}, 4 \mathrm{H}, 3 / 5-H_{\mathrm{ar}}\right), 7.04\left(\mathrm{~d},{ }^{3} J_{1 \mathrm{H} / 1 \mathrm{H}}=8.94 \mathrm{~Hz}, 8 \mathrm{H}\right.$, $\left.3 / 5-H_{\mathrm{ar}}\right), 7.38\left(\mathrm{~d},{ }^{3} J_{1 \mathrm{H} / 1 \mathrm{H}}=16.66 \mathrm{~Hz}, 2 \mathrm{H}, 3 / 5 \mathrm{CH}=\mathrm{CH}\right), 7.48$ $\left(\mathrm{d},{ }^{3} J_{1 \mathrm{H} / 1 \mathrm{H}}=8.73 \mathrm{~Hz}, 4 \mathrm{H}, 3 / 5-H_{\mathrm{ar}}\right), 8.42\left(\mathrm{~d},{ }^{3} J_{1 \mathrm{H} / 1 \mathrm{H}}=16.51 \mathrm{~Hz}\right.$, $2 \mathrm{H}, 3 / 5 \mathrm{CH}=\mathrm{CH})$.

8-Ethynyl-1,7-dimethyl-3,5-di[4-(di( $p$-methoxyphenyl)-amino)styryl]-2,6-diethyl-4,4-difluoro-4-bora-3a,4a-diaza-s-indacene (15). 14 (790.0 mg, $0.766 \mathrm{mmol}, 1$ eq.) is dissolved in THF : methanol $1: 1$ ( $80 \mathrm{~mL}$ of each), KF (222.6 mg, $3.831 \mathrm{mmol}, 5$ eq.) is added and the reaction solution is stirred for $30 \mathrm{~min}$ at $\mathrm{RT}$. Then $1 \%$ $\mathrm{CH}_{3} \mathrm{COOH}_{\mathrm{aq}}(50 \mathrm{~mL})$ and $\mathrm{CH}_{2} \mathrm{Cl}_{2}(150 \mathrm{~mL})$ are added. The organic layer is washed with water $(4 \times 100 \mathrm{~mL})$ until neutrality, dried over $\mathrm{Na}_{2} \mathrm{SO}_{4}$, filtered and the solvent is removed under vacuum. Yield: $710 \mathrm{mg}$ (blue-black solid), 97\%. $\lambda_{\max }(\mathrm{DCM}) / \mathrm{nm}=$ $781\left(\varepsilon / \mathrm{M}^{-1} \mathrm{~cm}^{-1}=49415\right), 580$ (22 659), 461 (16994), 372 (49970). FT-IR (ATR): $\nu_{\max } / \mathrm{cm}^{-1}=3274(\mathrm{w}), 2961(\mathrm{w}), 1587$ (m), 1500 (s), 1240 (m), 1171 (m), 1033 (m), 821 (m). ${ }^{1} \mathrm{H}-\mathrm{NMR}$ $(300 \mathrm{MHz}$, THF-d 8$): \delta / \mathrm{ppm}=1.24\left(\mathrm{t},{ }^{3} J_{1 \mathrm{H} / 1 \mathrm{H}}=7.17 \mathrm{~Hz}, 6 \mathrm{H}\right.$, 2/6- $\left.\mathrm{CH}_{2} \mathrm{CH}_{3}\right), 2.53\left(\mathrm{~s}, 6 \mathrm{H}, 1 / 7-\mathrm{CH}_{3}\right), 2.78\left(\mathrm{q},{ }^{3} J_{1 \mathrm{H} / 1 \mathrm{H}}=7.44 \mathrm{~Hz}\right.$, $4 \mathrm{H}, 2 / 6-\mathrm{CH}_{2} \mathrm{CH}_{3}$ ), 3.80 (s, 12H, OMe), 4.69 (s, $\left.1 \mathrm{H} ; \equiv H\right), 6.88$ $\left(\mathrm{d}+\mathrm{d},{ }^{3} J_{1 \mathrm{H} / 1 \mathrm{H}}=7.02 \mathrm{~Hz}, 4 \mathrm{H}+8 \mathrm{H}, 3 / 5-H_{\mathrm{ar}}\right), 7.08\left(\mathrm{~d},{ }^{3} J_{1 \mathrm{H} / 1 \mathrm{H}}=\right.$ $\left.8.94 \mathrm{~Hz}, 8 \mathrm{H}, 3 / 5-H_{\mathrm{ar}}\right), 7.28\left(\mathrm{~d},{ }^{3} J_{1 \mathrm{H} / 1 \mathrm{H}}=16.74 \mathrm{~Hz}, 2 \mathrm{H}\right.$, $3 / 5 \mathrm{CH}=\mathrm{CH}), 7.41\left(\mathrm{~d},{ }^{3} J_{1 \mathrm{H} / 1 \mathrm{H}}=8.73 \mathrm{~Hz}, 4 \mathrm{H}, 3 / 5-H_{\mathrm{ar}}\right), 7.63$ $\left(\mathrm{d},{ }^{3} J_{1 \mathrm{H} / 1 \mathrm{H}}=16.60 \mathrm{~Hz}, 2 \mathrm{H}, 3 / 5 \mathrm{CH}=\mathrm{CH}\right)$.

8-[(4-(2-Carboxy-2-cyanovinyl)phenyl)ethynyl]-1,7-dimethyl3,5-di[4-(di( $p$-methoxyphenyl)amino)styryl]-2,6-diethyl-4,4-difluoro4-bora-3a,4a-diaza-s-indacene (16). Under dry and oxygen-free conditions, 12 (280.1 mg, $0.939 \mathrm{mmol}, 3$ eq.), $\mathrm{Pd}\left(\mathrm{PPh}_{3}\right)_{4}$ (21.7 mg, $0.019 \mathrm{mmol}, 0.06$ eq.), CuI (2.4 mg, $0.013 \mathrm{mmol}$, 0.04 eq.) and $\mathrm{NEt}_{3}(0.20 \mathrm{~mL}, 1.408 \mathrm{mmol}, 4.5$ eq.) are dissolved in dry THF (15 mL). Then, 15 (300.0 mg, $0.313 \mathrm{mmol}, 1$ eq.) is likewise dissolved in dry THF (20 mL) and added dropwise over $3 \mathrm{~h}$ at RT to the reaction solution. After further $60 \mathrm{~min}$ stirring at RT, the solvent is removed. The raw product is purified by column chromatography starting with cyclohexane : ethyl acetate $2: 1+1 \%$ of glacial acetic acid, then the solvent is changed to $\mathrm{CH}_{2} \mathrm{Cl}_{2}$ followed by a change to $\mathrm{CH}_{2} \mathrm{Cl}_{2}$ : methanol $20: 1$ with a gradient to $10: 1$. The product fractions are collected and concentrated. The pure product is precipitated from ethanol, washed with ethanol, methanol, hexane and water. Yield: $170 \mathrm{mg}$ (green-black solid, $R_{\mathrm{f}}\left(\mathrm{SiO}_{2} ; \mathrm{CH}_{2} \mathrm{Cl}_{2}\right.$ : methanol $\left.10: 1\right)=$ $0.41), 48 \%$. $\lambda_{\max }(\mathrm{DCM}) / \mathrm{nm}=835\left(\varepsilon / \mathrm{M}^{-1} \mathrm{~cm}^{-1}=28272\right), 611$ (27 287), 403 (52 941). FT-IR (ATR): $\nu_{\max } / \mathrm{cm}^{-1}=3476$ (br), 2930 (w), $2210(\mathrm{w}), 1581$ (m), 1500 (s), 1439 (w), 1323 (w), 1234 (m),
1171 (s), 1031 (m), 821 (m). ${ }^{1} \mathrm{H}-\mathrm{NMR}$ (300 MHz, DMSO-d ${ }_{6}$ ): $\delta / \mathrm{ppm}=1.13\left(\mathrm{t},{ }^{3} J_{1 \mathrm{H} / 1 \mathrm{H}}=7.14 \mathrm{~Hz}, 6 \mathrm{H}, 2 / 6-\mathrm{CH}_{2} \mathrm{CH}_{3}\right), 2.49(\mathrm{~s}, 6 \mathrm{H}$, $\left.1 / 7-\mathrm{CH}_{3}\right), 2.67\left(\mathrm{q},{ }^{3} J_{1 \mathrm{H} / 1 \mathrm{H}}=6.75 \mathrm{~Hz}, 4 \mathrm{H}, 2 / 6-\mathrm{CH}_{2} \mathrm{CH}_{3}\right), 3.75$ $(\mathrm{s}, 12 \mathrm{H}, \mathrm{OMe}), 6.76\left(\mathrm{~d},{ }^{3} J_{1 \mathrm{H} / 1 \mathrm{H}}=8.67 \mathrm{~Hz}, 4 \mathrm{H}, 3 / 5-H_{\mathrm{ar}}\right), 6.92$ $\left(\mathrm{d},{ }^{3} J_{1 \mathrm{H} / 1 \mathrm{H}}=9.03 \mathrm{~Hz}, 8 \mathrm{H}, 3 / 5-H_{\mathrm{ar}}\right), 7.05\left(\mathrm{~d},{ }^{3} J_{1 \mathrm{H} / 1 \mathrm{H}}=8.88 \mathrm{~Hz}, 8 \mathrm{H}\right.$, $\left.3 / 5-H_{\mathrm{ar}}\right), 7.20\left(\mathrm{~d},{ }^{3} J_{1 \mathrm{H} / 1 \mathrm{H}}=16.39 \mathrm{~Hz}, 2 \mathrm{H}, 3 / 5 \mathrm{CH}=\mathrm{CH}\right), 7.38(\mathrm{~d}$, ${ }^{3} J_{1 \mathrm{H} / 1 \mathrm{H}}=16.36 \mathrm{~Hz}, 2 \mathrm{H},+\mathrm{d}, 4 \mathrm{H},{ }^{3} J_{1 \mathrm{H} / 1 \mathrm{H}}=8.22 \mathrm{~Hz}, 3 / 5 \mathrm{CH}=\mathrm{CH}+$ $\left.3 / 5-H_{\mathrm{ar}}\right), 7.72\left(\mathrm{~d},{ }^{3} J_{1 \mathrm{H} / 1 \mathrm{H}}=8.22 \mathrm{~Hz}, 2 \mathrm{H}, 8-H_{\mathrm{ar}}\right), 7.95\left(\mathrm{~d},{ }^{3} J_{1 \mathrm{H} / 1 \mathrm{H}}=\right.$ $\left.8.34 \mathrm{~Hz}, 2 \mathrm{H}, 8-H_{\mathrm{ar}}\right), 8.00(\mathrm{~s}, 1 \mathrm{H}, \mathrm{Ph}-\mathrm{C} H=\mathrm{C}(\mathrm{COOH})(\mathrm{CN})) \mathrm{ppm}$.

8-[(4-(1,3-Dioxolanyl)phenyl)ethynyl]-1,3,5,7-tetramethyl-2,6diethyl-4,4-difluoro-4-bora-3a,4a-diaza-s-indacene (17). Under dry and oxygen-free conditions, 2-(4-iodophenyl)-1,3-dioxolane (4.54 g, $16.453 \mathrm{mmol}, 3$ eq.), $\mathrm{Pd}\left(\mathrm{PPh}_{3}\right)_{4}$ (0.38 g, $0.329 \mathrm{mmol}$, 0.06 eq.), $\mathrm{CuI}$ (4.2 mg, $0.219 \mathrm{mmol}, 0.04$ eq.) and $\mathrm{NEt}_{3}(3.5 \mathrm{~mL}$, $25.250 \mathrm{mmol}, 4.7$ eq.) are dissolved in dry THF $(80 \mathrm{~mL})$. Then, 11 (1.80 mg, $5.484 \mathrm{mmol}, 1$ eq.) is dissolved in dry THF $(20 \mathrm{~mL})$ and added dropwise over $3.5 \mathrm{~h}$ at RT to the reaction solution. After further $4 \mathrm{~h}$ stirring at RT, the solvent is removed. The residue is dissolved in $\mathrm{CHCl}_{3}$ and washed with water $(4 \times 100 \mathrm{~mL})$. The organic fraction is dried over $\mathrm{Na}_{2} \mathrm{SO}_{4}$ and filtered. After removal of the solvent, the raw product is purified by column chromatography with cyclohexane:ethyl acetate $6: 1$. Yield: $2.22 \mathrm{~g}$ (dark purple solid, $R_{\mathrm{f}}\left(\mathrm{SiO}_{2}\right.$; cyclohexane : ethyl acetate $6: 1)=0.47), 85 \% . \lambda_{\max }(\mathrm{DCM}) / \mathrm{nm}=579\left(\varepsilon / \mathrm{M}^{-1} \mathrm{~cm}^{-1}=30887\right)$, 542 (15 910), 395 (16 874). FT-IR (ATR): $\nu_{\max } / \mathrm{cm}^{-1}={ }^{1} \mathrm{H}-\mathrm{NMR}$ $\left(300 \mathrm{MHz}, \mathrm{DMF}-\mathrm{d}_{7}\right): \delta / \mathrm{ppm}=1.08\left(\mathrm{t},{ }^{3} J_{1 \mathrm{H} / 1 \mathrm{H}}=7.59 \mathrm{~Hz}, 6 \mathrm{H}\right.$, 2/6- $\mathrm{CH}_{2} \mathrm{CH}_{3}$ ), 2.44 (q, ${ }^{3} J_{1 \mathrm{H} / 1 \mathrm{H}}=7.59 \mathrm{~Hz}, 4 \mathrm{H}, 2 / 6-\mathrm{CH}_{2} \mathrm{CH}_{3}$ ), 2.51 $\left(\mathrm{s}, 6 \mathrm{H}, 3 / 5-\mathrm{CH}_{3}\right), 2.54\left(\mathrm{~s}, 6 \mathrm{H}, 1 / 7-\mathrm{CH}_{3}\right), 4.00-4.20(\mathrm{~m}, 4 \mathrm{H}$, $\left.\mathrm{CH}_{2}-\mathrm{CH}_{2}\right), 7.54\left(\mathrm{~d},{ }^{3} J_{1 \mathrm{H} / 1 \mathrm{H}}=8.37 \mathrm{~Hz}, 2 \mathrm{H}, 8-H_{\mathrm{ar}}\right), 7.59$ (d, $\left.{ }^{3} J_{1 \mathrm{H} / 1 \mathrm{H}}=8.43 \mathrm{~Hz}, 2 \mathrm{H}, 8-H_{\mathrm{ar}}\right)$.

\section{Acknowledgements}

We acknowledge financial support from the Graduiertenkolleg GRAKO 1640 (DFG).

\section{Notes and references}

1 A. Treibs and F.-H. Kreuzer, Justus Liebigs Ann. Chem., 1968, 718, 208.

2 D. Zhang, V. Martin, I. García-Moreno, A. Costela, M. E. Pérez-Ojeda and Y. Xiao, Phys. Chem. Chem. Phys., 2011, 13, 13026.

3 J. Karolin, L. B.-A. Johansson, L. Strandberg and T. Ny, J. Am. Chem. Soc., 1994, 116, 7801.

4 D. W. Domaille, L. Zeng and C. J. Chang, J. Am. Chem. Soc., 2010, 132, 1194.

5 K. Rurack, M. Kollmannsberger and J. Daub, Angew. Chem., Int. Ed., 2001, 40, 385.

6 L. Bonardi, H. Kanaan, F. Camerel, P. Jolinat, P. Retailleau and R. Ziessel, Adv. Funct. Mater., 2008, 18, 401.

7 R. K. Lammi, R. W. Wagner, A. Ambroise, J. R. Diers, D. F. Bocian, D. Holten and J. S. Lindsey, J. Phys. Chem. B, 2001, 105, 5341.

8 G. Ulrich, R. Ziessel and A. Harriman, Angew. Chem., Int. Ed., 2008, 47, 1184. 
9 A. Loudet and K. Burgess, Chem. Rev., 2007, 107, 4891.

10 R. Ziessel, G. Ulrich and A. Harriman, New J. Chem., 2007, 31, 496.

11 S. Kolemen, Y. Cakmak, S. Erten-Ela, Y. Altay, J. Brendel, M. Thelakkat and E. U. Akkaya, Org. Lett., 2010, 12, 3812.

12 S. Kolemen, O. A. Bozdemir, Y. Cakmak, G. Barin, S. Erten-Ela, M. Marszalek, J.-H. Yum, S. M. Zakeeruddin, M. K. Nazeeruddin, M. Grätzel and E. U. Akkaya, Chem. Sci., 2011, 2, 949.

13 D. Kumaresan, R. Thummel, T. Bura, G. Ulrich and R. Ziessel, Chem.-Eur. J., 2009, 15, 6335.

14 S. Erten-Ela, M. D. Yilmaz, B. Icli, Y. Dede, S. Icli and E. U. Akkaya, Org. Lett., 2008, 10, 3299.

15 T. Bura, N. Leclerc, S. Fall, P. Lévêque, T. Heiser, P. Retailleau, S. Rihn, A. Mirloup and R. Ziessel, J. Am. Chem. Soc., 2012, 134, 17404.

16 Y. Chen, L. Wan, D. Zhang, Y. Bian and J. Jiang, Photochem. Photobiol. Sci., 2011, 10, 1030.

17 V. Lin, S. DiMagno and M. Therien, Science, 1994, 264, 1105.

18 Z. Liu, A. A. Yasseri, R. S. Loewe, A. B. Lysenko, V. L. Malinovskii, Q. Zhao, S. Surthi, Q. Li, V. Misra, J. S. Lindsey and D. F. Bocian, J. Org. Chem., 2004, 69, 5568.

19 G. S. Wilson and H. L. Anderson, Synlett, 1996, 1039.

20 C. O. Hann and A. Lapworth, J. Chem. Soc. Trans., 1904, 85, 46.

21 S. Bednarz and D. Bogdal, Int. J. Chem. Kinet., 2009, 41, 589.
22 M. Karas, I. Fournier and M. Bolte, Acta Crystallogr., Sect. E: Struct. Rep. Online, 2005, 61, 0383.

23 H. L. Kee, C. Kirmaier, L. Yu, P. Thamyongkit, W. J. Youngblood, M. E. Calder, L. Ramos, B. C. Noll, D. F. Bocian, W. R. Scheidt, R. R. Birge, J. S. Lindsey and D. Holten, J. Phys. Chem. B, 2005, 109, 20433.

24 M. Thelakkat, R. Fink, P. Pösch, J. Ring and H.-W. Schmidt, Polym. Prepr. (Am. Chem. Soc., Div. Polym. Chem.), 1997, 1, 394.

25 K. Peter, H. Wietasch, B. Peng and M. Thelakkat, Appl. Phys. A: Mater. Sci. Process., 2004, 79, 65.

26 TURBOMOLE V6.3 2011, a development of University of Karlsruhe and Forschungszentrum Karlsruhe $\mathrm{GmbH}$, 1989-2007, TURBOMOLE GmbH, since 2007; available from http://www.turbomole.com, 2007.

27 K. Willinger, K. Fischer, R. Kisselev and M. Thelakkat, J. Mater. Chem., 2009, 19, 5364.

28 N. M. Loim and E. S. Kelbyscheva, Russ. Chem. Bull., 2004, 53, 2080.

29 N. Tsuboya, M. Lamrani, R. Hamasaki, M. Ito, M. Mitsuishi, T. Miyashita and Y. Yamamoto, J. Mater. Chem., 2002, 12, 2701.

30 M. Sommer, S. Hüttner and M. Thelakkat, Adv. Polym. Sci., 2010, 228, 123.

31 L. Bonardi, G. Ulrich and R. Ziessel, Org. Lett., 2008, 10, 2183. 